УДК 81’33:177

\title{
THE DISCURSIVE EMOTIONAL ASPECT OF IDEOLOGICAL TRANSITIONS IN THE VICTORIAN AGE
}

\author{
PINICH I. P. \\ Candidate of Linguistics, Associate Professor \\ Kyiv National Linguistic University \\ ipinich@hotmail.com
}

\begin{abstract}
Introduction. The discursivity of emotions in ideology enactment is frequently questioned in ideology critique, whereas modern historical, psychological and social studies recognize the pertinence of emotions in shaping discursive practices. The current study argues the modulatory function of moral emotions in defining the complex phenomenon of Victorian ideology. Therefore, the dynamics of ideology proliferation is believed to ground in the emotional coherence of moral judgments.
\end{abstract}

Purpose. The paper aims at investigating the large-scale process of ideology transitions characteristic of the Victorian period and beyond. The study lies in the assumption that ideological shifts pertaining to the period of the late 18th through early 20 th centuries can be additionally tested in the term frequency of ideologically relevant issues as represented in the British English corpus brought by Google Books.

Methods. Successive implementation of dictionary entry analysis, componential analysis, and machine based frequency analysis has testified to the plausibility of presumptions on the correlation of ideology long-term dynamics to the dominant emotional repertoires of the times.

Results. The inventory of relevant ideologies has been provided in conformity with the earlier findings on the association of lexical representation of ideologies and moral emotions labels. The list of propositional ideologemes as fundamental doctrinal units of ideologies has been established basing on the common semantic features of nouns and adjectives defining the respective social practices in the contemporary dictionary entries. A frequency analysis aided by Google Books Ngram Viewer has evinced the heterogeneous process of ideologeme rises and declines.

Conclusions. The ideological nature of moral emotions translates to their potency of modification or adjustment of propositional ideologemes in their further processing both for maintenance and/or transit. The trends are displayed in the dynamics of interest to the relevant ideological matters, in the changes of the semantic structure of lexicalized ideologemes and the co-occurrence of emotion labels with the doctrinal linguoideologemes.

Keywords: discursivity, moral emotions, ideological transition, Victorian ideology, ideologeme.

\section{ДИСКУРСИВНИЙ ЕМОЦИЙНИЙ АСПЕКТ ІДЕОЛОГІЧНИХ ПЕРЕХОДІВ У ВІКТОРІАНСЬКУ ДОБУ}

ПІНІЧ Ірина Петрівна

кандидат філологічних наук, доцент

Київський начіональний лінгвістичний університет ipinich@hotmail.com

Bcmyn. Попри широке визнання важливості емоцій у формуванні дискурсивних практик в історичних, психологічних та соціальних дослідженнями, їхню дискурсивну функцію в становленні ідеологій часто піддають сумніву у філософському аналізі ідеологій. Натомість виокремлюють пропозиційні доктринні та непропозиційні оцінні компоненти ідеологій. Пропоноване дослідження обстоює модуляторну функцію моральних емоцій у визначенні комплексного феномену Вікторіанської ідеології. Важливо довести, що динаміка поширення ідеології грунтується на емоційній когерентності моральних суджень. 
Mema cmammi - проаналізувати широкомасштабні процеси ідеологічних переходів, характерних для вікторіанської доби та поза ії межами. В основі дослідження лежить припущення, що ідеологічні зсуви, які притаманні періоду кінця XVIII - початку $\mathrm{XX}$ сторіччя, можуть бути додатково протестовані за допомогою частотності термінів на позначення ідеологічно релевантних понять, репрезентованих у корпусі британської англійської мови Google Books.

Meтоди. Шляхом послідовного застосування аналізу словникових дефініцій, компонентного аналізу та машинного аналізу частотності термінів підтверджено вірогідність припущень про зв'язок довгострокової динаміки ідеологій із домінантними емоційними репертуарами тих часів.

Результати. На основі аналізу взаємозустрічності лексичного втілення ідеологій і номінативних позначень моральних емоцій визначено інвентар ідеологій, характерних для вікторіанських часів. Вивчення спільних семантичних ознак іменників та прикметників на позначення відповідних соціальних практик у словникових визначеннях тогочасності дало змогу створити типологію пропозиційних ідеологем як фундаментальних доктринних одиниць. Аналіз частотності термінів, виконаний за допомогою пошукової машини Google Books Ngram Viewer, засвідчив тенденцію до неоднорідності становлення та занепаду ідеологем.

Висновки. Ідеологічна природа моральних емоцій полягає в їхньому потенціалі до модифікації пропозиційних ідеологем у процесі їх подальшого когнітивного опрацювання задля утвердження та/або переходу в іншу ідеологічну систему. Ці закономірності виявляються у змінах семантичної організації лексикалізованих ідеологем, у взаємозустрічності номінацій моральних емоцій та доктринних лінгвоідеологем, а також у частотній зацікавленості лінгвоспільноти ідеологічно значущими питаннями.

Ключові слова: дискурсивність, моральні емоції, ідеологічний перехід, Вікторіанська ідеологія, ідеологема.

\section{Introduction}

Numerous modern scholarly accounts of ideology as a set of ideas and beliefs which are preeminently infused with irrationality and emotions (Fine \& Kennet, 1993; McAvoy, 2015) reverberate the original sensationalist theory of ideology propounded by Destutt De Tracy, where sensory aspects of cognition (along with memory, will, and judgment) are among the inborn human faculties that underlie the logical and psychological processes of generating ideas (Kennedy, 1979, p. 363; Head, 1985, p. 37-38). The view though has long been considered disputable and frequently brought forward the issue of emotional component of ideology arguable. The tendency rooted in the timeless dichotomies of idealism and materialism, metaphysics and science, objectivism and subjectivism, but more so in the antinomy of emotion and cognition.

The distinction set by Geuss in the organization of ideology constituents $(1981$, p. 5) dwells on the ideas of the Frankfurt school of critical theory and discerns between discursive or conceptual elements and non-discursive elements of ideology. The conceptual elements that involve ideas, concepts, and beliefs are the structural elements of ideology, as "they are givens" and comprise the belief system of a collectivity (Sartori, 1969, p. 401). The beliefs form the propositional side of an ideology, establish ideological conditioning of mind and serve as a "manifestation of the socially necessary consciousness" (Habermas, 1991, p. 88). The cognitive dimension of ideology allows for the classification of ideologies based on the "aboutness" of the beliefs. Therefore, religious, economic, political, legal, social, and moral ideologies are distinguished. Conversely, the irrational side of ideology evinces its functional properties, the efficiency of belief systems, and the intensity of these beliefs. Accordingly, the non-discursive elements embrace the psychological aspect of ideology enactment that of attitudes, rituals, habits, psychological dispositions, predilections, values, and desires (Geuss, 1981, p. 8). 
This notwithstanding, the non-discursive nature of emotions is often questioned nowadays in the affect theories: a sentimentalist theory of mind (cf. Slote, 2014), a theory of emotional coherence (cf. Thagard, 2008), social intuitionist model of moral judgment (cf. Haidt, 2012). The claim about the discursive nature of emotions has gained a strong position in psychological, social and anthropological studies. Contemporary historical studies of emotions claim the indispensable role of sensations in the sustenance of social structures and distribution of powers across the society (Rosenwein, 1998; Stearns, 1994), affective causality of historical events and centrality of emotions in the history of morality (Boddice, 2018). Modern social studies also give prominence in ideology maintenance and ideology shifts to the "feeling rules" (Hochschild, 1979) that form the undersides of ideology and serve as an expression of the worldviews of its subjects (Koch, 2013, p. 128).

The particular interest of the current paper is the "discursivity" function (Foucault, 1988, p. 206) of emotions both as constituents and modulators of ideologies. The study substantiates the hypothesis of ideological transitions incurred by the dominant emotional repertoires of the time. The purpose of the article is to test the assumption on the relation of concurrency of ideological shifts to the fluctuation of interest to the ideologically relevant issues in the British English corpus brought by Google Books service. The paper argues that rising ideologies take over the ideologies in wane through the emotive domain of "ideological passion" (Sartori, 1969, p. 403). The transitory mechanisms within ideologies involve the cognitive procedures of acquisition, revision, and reviewing of the "ideological heritage" and further rejection of the contested elements or re-establishment of the admitted ones. The dynamics of ideology enactment though dwells on the "emotional coherence" of moral judgment and action-motivation reasoning (Thagard, 2006, p. 18) that form the psychological aspect of ideology appeal.

Moral emotions occupy the central position in the study of ideology transitions in the Victorian times. Firstly and more generally, the choice has been made under assumption much in concordance with the Parsonian model of cognitive, cathectic, and evaluative orientations in social systems (Parsons, 1991, p. xx). It follows that moral coerce and cathectic energy along with knowledge and cognition are among the key components in the maintenance of social order, meanwhile moral thinking forms the basis for "cultural ideology" (Getz \& Narvaez, 1999, p. 447). Secondly, the tripartite organization of moral themes in a society as viewed by a modern moral theory (cf. Haidt, 2012, p. 115-118) proves congenial to the analysis of the changes in the structure of Victorian moral identity ranging from the ethic of divinity to the ethic of autonomy. Furthermore, modern psychological studies exhibit that falsifiability or testability of belief systems is but the less important than irrational unfalsifiability aspects of moral opinion as regards ideological convictions (Friesen, Campbell, \& Kay, 2015, p. 155).

\section{Lingual representation of ideology}

Though, a "psychological approach to ideology enactment" (Pinich, 2019) does not necessarily involve the non-objectivist view of language exclusively. The paper argues that ideologies can find their reification in language through a system of their fundamental units - ideologemes. The ideologeme is a sygnificational praxemic unit of higher abstraction having the potency of shaping discursive practices. The bipartite nature of ideologemes translates to refraction of ideological mental units into paradigms of their potential lingual representations called linguoideologemes (Pinich, 2018d). Consequently, based on the prototype theory (Rosch, 1975) the following distinction among the linguoideologemes could be made:

1) Full linguoideologemes are linguistic representations of doctrinal ideologemes, descriptive in their nature that convey the propositional aspect of an ideology by outlining the doctrinal statement and establish the core of the conceptual structure of an ideology.

2) Partial linguoideologemes denote ideologically pertinent aspects of social ethics admitting action or state motivation. They are imprints of ideologically laden attitudes displaying in-group favouritism or out-group derogation that involve moral judgment of ideologically relevant issues. 
3) Acquired linguoideologemes stand for linguistic units that inherit their ideological potency through the content of lingual representation of other non-dominant ideologies in the context. These units originally not ideologically laden acquire their relevance in the context of situation or action. Rhetorical figures, slogans, and citations are also among the linguistic means included in this type.

The efficiency of ideology enactment and proliferation resides in the extensive implementation of its verbal representation in discourse. This view underpins the fundamental claim of critical discourse analysis that attitude and knowledge form an ad hoc basis for sustaining the distribution of powers in a society (Van Dijk, 1998, p. 167) and from discursively constructed ideological opinions and ideological attitudes. Thus, full ideologemes can serve as the linguistic means for testability of ideological doctrines, whereas partial linguoideologemes are verbal means for substantiation the unfalsifiability of one's belief system and in the intra-group communication can be deployed with the pragmatic function of social marginalization and intractability, disregarding the propositional components of ideology. Partial linguoideologemes comprise an extensive pool of linguistic means for ideology penetration into the "non-ideological knowledge systems" (Žižek, 1994, p.15).

The co-occurrence of linguoideologemes testifies to the association of ideologemes in the systems of interconnected dominant and non-dominant ideologies of the time. The claim has been tested in a series of consecutive studies (Pinich 2018a; 2018b; 2018c) on the basis of qualitative and quantitative analyses of the corpus of British fiction texts retrieved from CLMET 3.1 (Corpus of Late Modern English Texts) employing the text manipulating techniques of the free software KH Coder. The research involving preeminently co-occurrence and term frequency analyses of moral emotion labels, as lexical representation of moral ideologemes, tested the dynamics in their conceptual structure in relation to the rising secular ideologies. Subsequently, the ideology transition mechanism has been defined as a gradual process intermediated by the modulation of ideologemes via the prevailing emotion scenarios of the Victorian morality. The transitory process subsumes moral ideologemes forming "mental configuration" (Bianca, 2017, p. 41) with propositional ideologemes conferring in this way an ideological ignite to a rising ideology. The feeling rules underlying ideologies dynamics are communicated in texts and enter the system of shared knowledge. Consequently, the content of emotions and the recognized display patterns make the attitudinal and motivational ideological components which are mirrored and subtly proliferated in the verbal messages of texts, fiction inclusively.

3. Reflection of Victorian ideology dynamics in the British English corpus of Google Books

This study is a reconnaissance into the plausibility of the earlier findings on the ideological discursivity of moral emotions throughout the period from the late 18th to the early 20th century. The period encompasses the pre-Victorian through post-Victorian times that is congruent with the analysis of long-term processes for ideological decline in religious beliefs and the rise of secular ideologies. The specialized British English corpus of Google's text corpora serves the source of the machine-based analysis employing an online search engine Google Ngram Viewer. The study is supplementary to the previous in-depth analysis of ideologeme association and focuses on the presence and dynamics of lexical representation of relevant ideologemes in the British texts dating from the 1780 s to the 1920 s.

The inventory of moral ideologemes is confined to the typology of moral responses involving positive and negative moral emotions as defined by Haidt (2003) and grey-zone moral reactions (Ben-Zeev, 2002). Positive moral emotions resulting from the recognition of appropriateness of moral behaviour are divided into other-praising emotions ranging from elevation to gratitude and pride, and other-suffering moral emotions of sympathy/compassion (Haidt, 2003). Negative moral emotions are triggered by denunciation of moral violations, and fall into two groups of other-condemning and self-conscious emotions. Other-condemning moral emotions involve anger, disgust, and contempt, while self-conscious negative emotions encompass prototypical moral emotions of guilt, shame, 
and embarrassment (ibid.). Meanwhile, grey-zone moral reactions of envy, jealousy, resentment, and ressentiment (bitterness) are infused by unjustified insults and undeserved inferiority and have the claim to justice (Fassin, 2013). Therefore, the moral linguoideologemes under scrutiny are represented by the respective moral emotion labels of elevation, gratitude, pride, sympathy, shame, guilt, embarrassment, anger, disgust, contempt, envy, jealousy, resentment, and bitterness.

The choice of relevant propositional ideologemes is substantiated by their relation to the actual ideologies of the times tested in my previous studies and grouped around RELIGION, ECONOMY, MONEY\&FINANCE, POLICY\&LAWMAKING, CRIME\&PUNISHMENT, SOCIAL STATUS, GENDER, MORALITY\&PRECEPTS, FAMILY\&HOME, and WAR\&WARCRAFT. The co-occurrence of their lexical representation to the labels of moral emotions signals their interconnectedness and predetermines their further co-placement in the search line of Ngram Viewer. The list though is not exhaustive and might seek an extension of which I am quite aware. Yet, the catalogue reverberates the views of historians who argue the amplitude of Victorian minds varying from teleological to utilitarian, from virtuous to sinful, and from altruistic to individual (Eccleshall, 2002; Himmelfarb, 1995). The view entails that Victorians, known for the "rigidity of ideas, circumstances, values, and attitudes" (Purchase, 2006, p. xi) and demonstrating the resilience of the puritan ethos in wane, concomitantly exhibited new, liberal and industrious approach to life within the domineering middle class. Therefore, the rise of secular ideologies witnesses a whole range shift to the canonized concepts of "work, bustle, determination, energy, purpose, progress, individualism, and charity" (ibid.). Nevertheless, this multiminded basis of Victorian ethos serves as the starting point of Victorian ideology characterized by the transitory nature of many of its ideologemes that maintained significant links to the religious ideology forming a network of new associations to the dominant rising ones.

The selection of the linguoideologemes is based on the principle of association and entails the compilation of lemmatized noun and/or adjective forms of the associated lexical units retrieved from contemporary dictionary entries. Subsequently, religious linguoideologemes under analysis are sketched based on the Roget's classification of religious affectations (1879, p. xiv) divided accordingly into institutions (church, temple, canonicals, clergy, and ritual), doctrines (theology, revelation, Orthodoxy), acts (worship, idolatry, spell), and sentiments (piety, impiety, irreligion). Legal linguoideologemes are distinguished in accordance with the definitions of law and jurisprudence provided by Webster's Complete Dictionary of the English Language (1886, pp. 732, 757) involving power matters (authorities, judicial power, judicial authority, jurisdiction, legal power, and power of legislating) and regulations (administration of justice, judiciary department, justice, statute, edict, regulation, decree, rights, law, and customs).

Morality issues include ethics, moral, and moral principles, duty, virtue, standard, character and intention (ibid., p. 858). Gender issues are reflected in the linguoideologemes to denote sex and marital status (female, woman, lady, mistress, gentleman, husband, and wife), origin (middle rank, above yeomanry, above vulgar, husband-knight, earl-farther, good family, good breeding), domestic chores (domestic affairs, household) and an outstanding behaviour (gentle manners, refined manners) as outlined in the entries on gender, gentleman, gentlewoman, and lady (ibid., pp. 563, 565, 747). Crime (ibid., p. 312-313) and punishment (ibid., p. 1062) find their representation through the system of linguoideologemes organized around an object of violation (law, human, divine, morality, public welfare), wrongdoing (violation, disobedience, murder, theft, crime, offense, misdemeanor, sin, vice, wrong), trespasser (offender, criminal), legal action (enforcement, law, accuse, charge, fault, legal action, guilty, verdict), and retribution (suffering, pain, loss, calamity).

Financial issues are refracted in the groups of linguoideologemes retrieved from the entries on economy and finance (Webster's Complete Dictionary of the English Language, 1886, pp. 427, 512). Consequently, ECONOMY, MONEY\&FINANCE encompass money management (expenses, waste, loss, frugality, prudence, savings, domestic affairs, household matters), financial policy 
(corporation, economy, state, system, rules, regulations, distribution, resources, Jewish economy, political), money matters (income, revenue, financial operations, public revenues, public money, funds), capital management and beneficiary (treasurer, financier, economist, ruler, receiver, farmer). The co-arrangement of moral and propositional linguoideologemes dwells on their associations prompted in the earlier studies. For the convenience of reading graphs not all visual representations of linguoideologemes frequency are presented in the paper, which outlines only the general tendencies in the dynamics of interest to the ideologically relevant issues.

3.1 Guilt and shame in the procurement of legal and moral ideologies

The establishment of guilt-culture in the Western tradition by the beginning of the 19th century (Dein, 2013, p. 128) involved numerous changes in the systems of related ideologemes. The feeling of guilt was brought to the extreme point of neurosis through the Protestant religious practices cultivating individual responsibility and individual consciousness. This shift marked a transit from commonality to individualism and yielded the split in the structure of personal identity by "distinguishing religious identity from moral identity" (Hardy, Nadal \& Schwartz, 2017). As the feeling of guilt at a moral failure threatening the parochial community was gradually dissolving, the spiritual hold of the divinity ethic in the Victorian era went in decline (Xiao, 2015). Therefore, the general decline of frequency of religious linguoideologemes in the corpus duplicates the tendencies of a dwindling interest to guilt and shame as observed in the occurrences of emotion labels (See Graph 1).

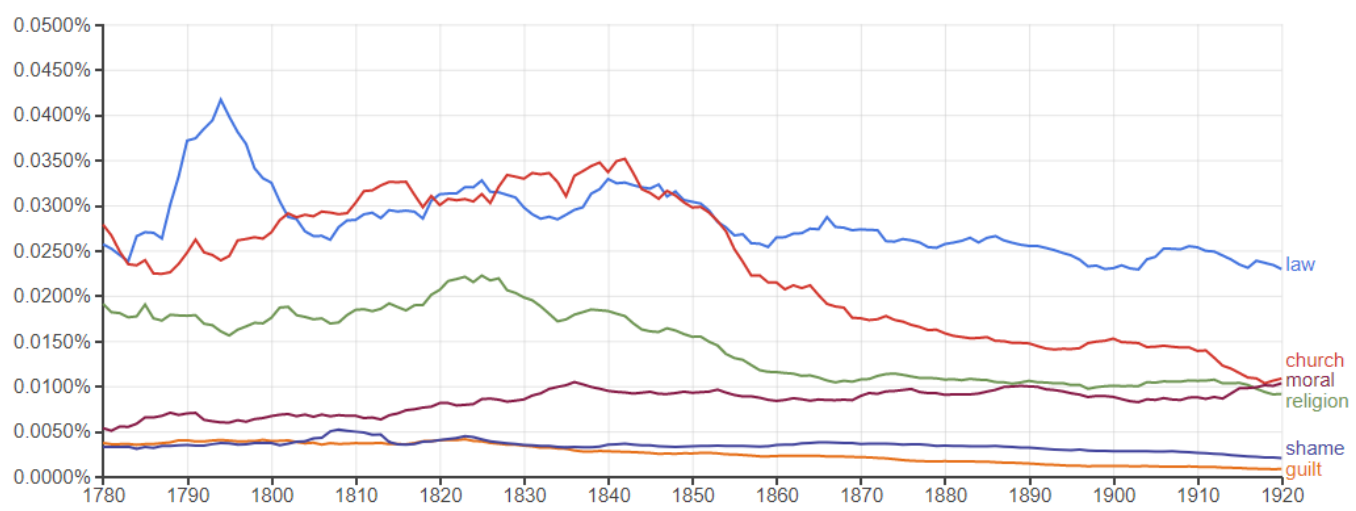

Graph 1. Occurrences of guilt/shame related linguoideologemes in the British English corpus, generated with the help of Google Books Ngram Viewer

The negative trend was favoured by the legislative takeover in the system of authorized discipline against guilt since the status of the English judicial system by the early 19th century had already achieved the level close to total regulation (Conley, 1986, p. 519). Consequently, the interest to legal matters surpasses the mentions of religion in the British texts of the late 18th early 20th centuries. The interest though is preserved to the ecclesiastical issues as the frequency of church occurrences from the beginning by the middle of the 19th century has the range similar to that of law occurrences and varies throughout the period from 0,02 to $0,01 \%$ exhibiting the general decline since the $1850 \mathrm{~s}$ characteristic of most religious linguoideologemes.

The rise of guilt triggered a deeper internalization of shame, moving the accent in emotion elicitors from the "consciousness of guilt or injured reputation" to the exposure of "that which nature promotes to conceal", therefore interconnected with "decency and decorum" (Webster's Complete Dictionary of the English Language, 1886, p. 1213). The expansion of the meaning with the move to the exterior ethical matters is mirrored in the similar ratio of shame to guilt as in moral to religion. Morality issues subsequently exhibit a wavelike interest to them: among the salient ones - duty starting from 
$0,01 \%$ in the 1780 s and reaching the highest of $0,016 \%$ in 1830 , goes down again to $0,01 \%$ in the 1890 s to slightly rise to $0,011 \%$ by the 1920 s, and moral mentions which increase from $0,005 \%$ in the 1780 s to $0,01 \%$ in 1836 then hit the lowest by the end of the 19th century to restore its positions of $0,01 \%$ by the $1920 \mathrm{~s}$.

\subsection{Sympathy and gratitude as transitory religious ideologemes}

Sympathy occupies the flagship position in a large-scale transit of religious ideologemes to the rising secular ideologies and is mediated by the principles of morality and precepts of the time. The feeling of gratitude as one of other-praising moral emotions along with awe and elevation evinces not a lesser relation to virtuous ideologemes. The action/state motivation that seeks the feeling of purity and optimism at looking on the exemplary behaviour or else yielding beneficiary's inclination to express friendliness and gratitude all have the potency of stirring a deep religious feedback betraying a strong incline to pro-sociality.

Defined as a hallmark of sentimentalist model of a society by Scottish philosophers Hume (1978) and Smith (2002), sympathy bridges an originally religious virtue ideologeme associated with temperance, charity, prudence, fortitude, justice, and kindness with a moral ideologeme proper. The centrality of its function lies in the retainment of stability to well-established ideological links which guaranteed the feeling of emotional safety and reciprocity on the recognized religious turf. And whereas virtuous sympathy claims altruistic egalitarianism, its moral incarnation retains the features of individualism and deontological ethics - intrapersonal emotional perception prescribed by the expectations of the society. The gradual trend towards the increase of interest to sympathy $(0,0006-0,004 \%)$ can be observed in Graph 2 , which is also indicative of a symmetrically opposite dynamics of other female-related phenomena of gratitude $(0,003-0,0016 \%)$ and piety $(0,003-$ $0,0008 \%$ ), very much in conformity with the general tendency of a waning religious ideology.

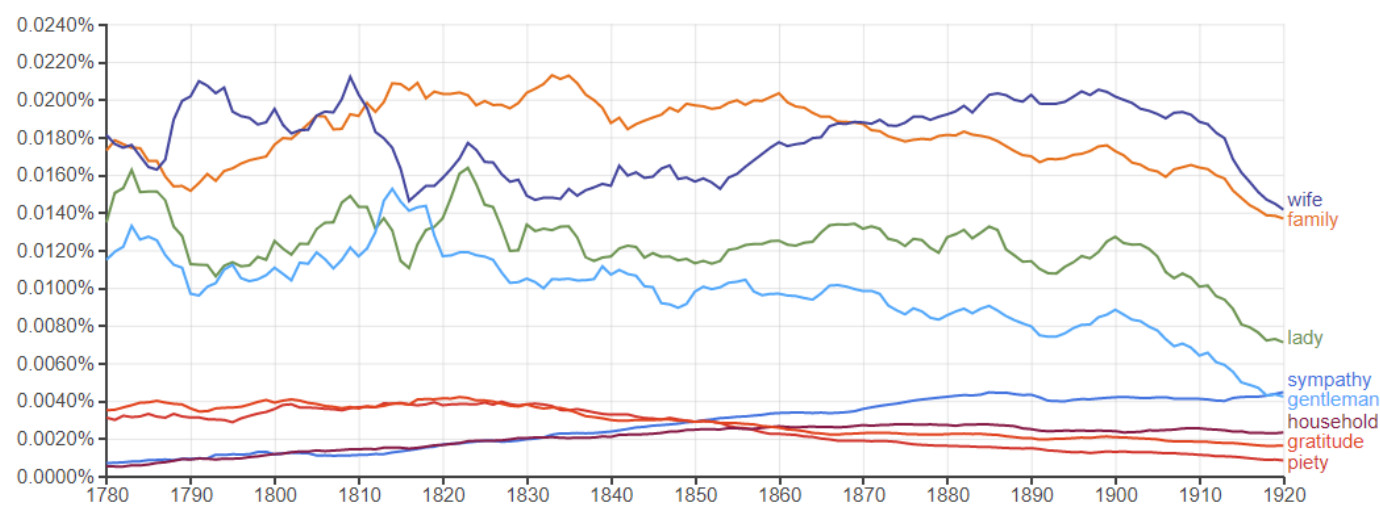

Graph 2. Occurrences of sympathy / gratitude related linguoideologemes in the British English corpus, generated with the help of Google Books Ngram Viewer

Further rise of capitalist utilitarian ideology modifies the social dimension of primarily universal human propensity to sympathize and channels it to a narrow, personal space "contained in the feminine and domestic spheres of life" (Lowe, 2007, p. 124-125). The ideologeme therefore becomes secluded to the "femininity issues which are strongly interconnected with the nature of power, substantiated by the Victorian capitalism" (Purchase, 2007, p. 76). The stability of gender hierarchy in the Victorian period procured men domination in every sphere of life (Purchase, 2007, p. 73). The definiteness of gender distinctions remained salient throughout the period. Therefore, the fluctuations of the interest to gender linguoideologemes denoting sex and marital status are alike, extending between $0,01 \%$ and $0,02 \%$ and evincing a general surge in the 1820 s and a common decline in the late 1890 s with the rise 
of "contrary to laissez-faire ideology - the ideology of militarism, nationalism, and imperialism" (Himmelfarb, 1995, p. 318).

3.3 Jealousy, envy, and bitterness in facilitating the transition of ideologeme JUSTICE

Another ideological shift pertaining to the period is the transit of religious ideologeme JUSTICE to the CRIME\&PUNISHMENT ideology. The change involved the divergence of the system of justice splitting the general justice into "distributive, procedural, and retributive" (Sabbagh \& Shmitt, 2016). Utilitarian retributive justice underpinned the retreat from the rightful divine discipline for the failings of humanity and marked the turn to the authorized criminal sanctions proportionate to the moral deficit of the criminal (Conley, 1986, p. 519-520). The transit was substantiated by and for the purpose of preserving the power balance in the society. The inhibition of outward display of "envy and jealousy linked to unjust and undeserved inferiority" (Ben-Ze'ev, 2002) was attributed to indecency and more so to a sinful reaction. The inert and benign nature of the feelings was devoid of any dynamism needed for bringing in the changes to the social and financial standing of the dominated that resulted in the interiorization of a long-lasting moral attitude of ressentiment. The inaction and bitterness amounted to the exclusivity of "Victorian pain" delineated from the social suffering and characterized by distinguished individualism, solitude, and privacy (Ablow, 2017, p. 23).

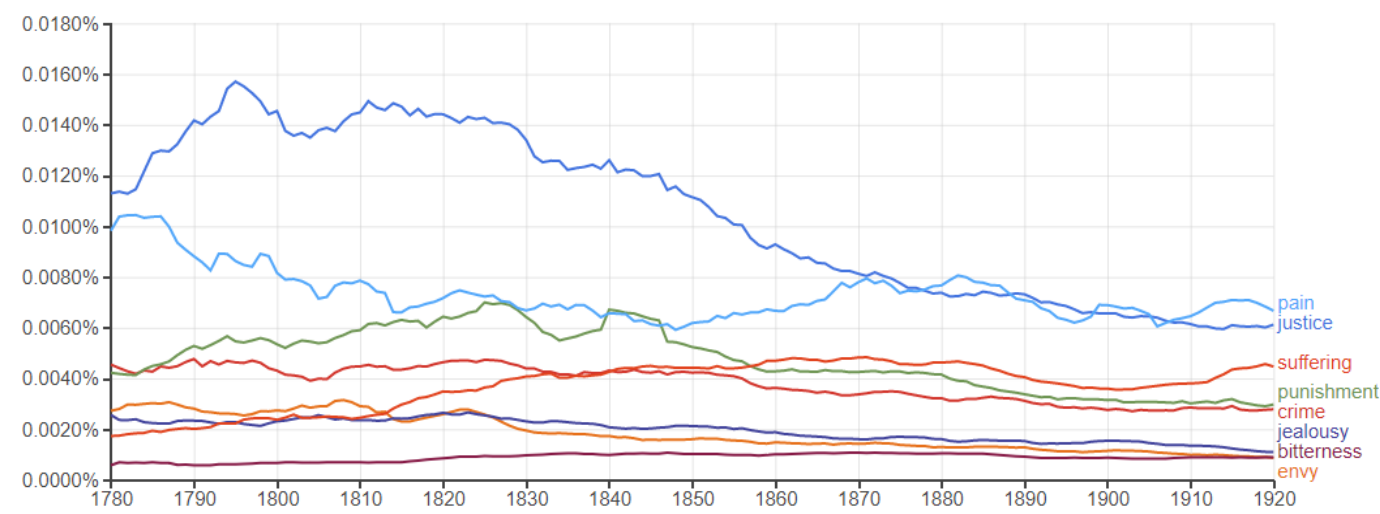

Graph 3. Occurrences of justice-related linguoideologemes in the British English corpus, generated with the help of Google Books Ngram Viewer

Successful placation of vice-related emotion display renders a gradual loss of interest to short-lived moral emotions of envy $(0,002-0,0009 \%)$ and jealousy $(0,002-0,001 \%)$. Conversely, bitterness frequency shows the positive dynamics in accord with the occurrence of other retributive feelings of pain and suffering. Though, the interest to pain in the corpus exhibits a slide from $0,01 \%$ to $0,005 \%$ by the middle of the 19th century with the following restoration of the interest in the 70s and $80 \mathrm{~s}$ of the century linked purportedly to its inconceivable nature questioned by the late Victorian writers (ibid., p. 10). Meanwhile, the interest to punishment and crime slightly dwindles down with the highest indicators demonstrated around the middle of the century. The negative dynamics of both linguoideologemes shows a decrease by $0,002 \%$ from the initial indicator of $0,004 \%$. Morality issues exhibit a slow increase from $0,001 \%$ in the beginning of the period to $0,002 \%$ by the end of it. The trend was also incurred by outstretching the issues of moral code applied to men in power (Himmelfarb, 1995, p. 185) pushing the subordinated to seek their consolation in "the final proportions of eternal justice" (ibid., p. 12).

3.4 Anger and resentment - a channeled ideological fervour of the times

According to Stearns' characterization of Victorian anger, the channeling of emotion involved a number of successive changes in its conceptual structure, one of which was directing anger to 
utilitarian competitiveness (1994). Thus, the establishment of anger linkage to economy and finance matters was a recognized practice for masculinity, whereas morality principles condemned anger in women and children. Gender distinctions in anger display favoured a two-party system of power relations; the authorized anger was compatible with the potency of the dominant group and its admittance in the dominated. The maintenance of power balance is observed in the dynamics of fluctuating interest to anger in the British English corpus (see Graph 3) which exhibits the median frequency of around $0,002 \%$. The highest indicators do not exceed the frequency of $0,003 \%$, but the lowest never go down below the median index. Meanwhile, resentment as a long-term attitude to injustice was deemed a sinful repining and lacked the ideological fervour. The tendency to the dissolvability of its cohesive power is also seen in the significant dive of the interest to the phenomenon from 0,003 to $0,001 \%$ by the beginning of the 1840 s and a gradual decline up to $0,0007 \%$ by the end of the period.

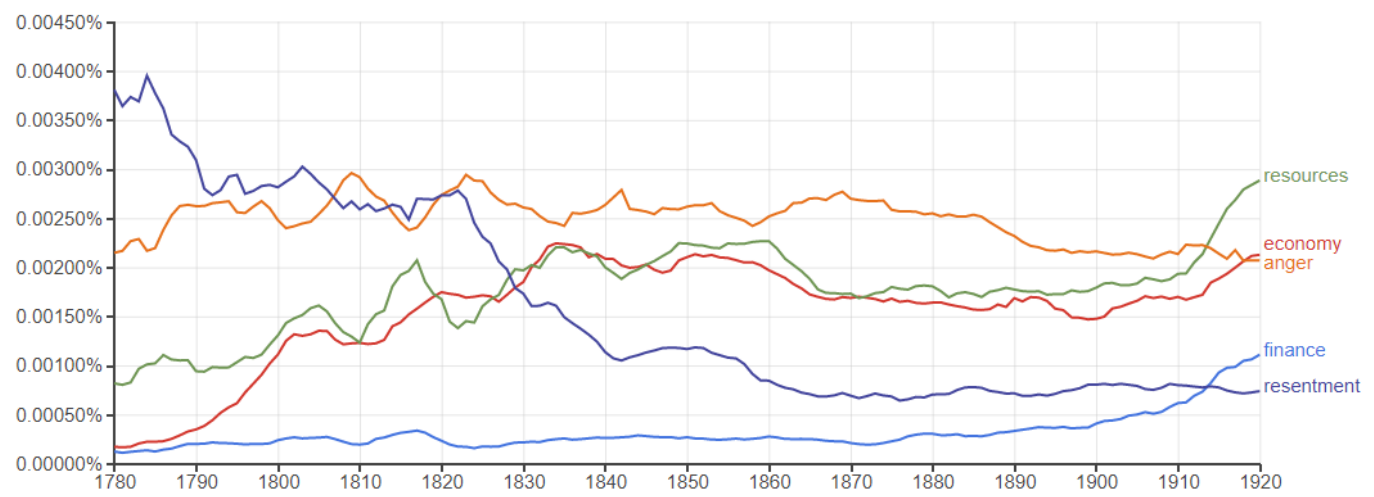

Graph 4. Occurrences of anger-related linguoideologemes in the British English corpus, generated with the help of Google Books Ngram Viewer

Along with the channeled other-condemning moral emotions the rise of interest to economic matters can be observed throughout the period. The financial policy issues as well as money matters and money management exhibit a steady interest to them with the prominence given to economy $(0,0001-0,002 \%)$ and resources $(0,0008-0,002 \%)$, losses $(0,0008-0,002 \%)$ and savings $(0,002-$ $0,004 \%)$, income $(0,0009-0,003 \%)$ and funds $(0,0006-0,001 \%)$. A decline of interest to public money $(0,002-0,001 \%)$ echoes the trend of lowering concern about prudence $(0,003-0,0007 \%)$ related to frugal management of household. Similarly, negative dynamics is shown in the occurrences of medieval treasurer with the frequency drop around 1830 from $0,001 \%$ and a gradual slide to $0,0003 \%$ by the end of the period. Instead, the rise of new job titles involved in managing finances, financier and economist, is displayed in the growing frequency of their mentions.

\section{Conclusions}

A large-scale transit of ideologemes in the Victorian era exhibits a significant shift of ideologies from religious to secular utilitarian ones. The pertinent changes are evinced in the extent of interest to the ideologically relevant issues throughout the period extending even beyond the years of Victoria's reign. The rise of propositional ideologemes encompassing the salient social practices of economy, finance, policy, law, jurisprudence and justice was mediated by the dominant emotional repertoires established through the system of moral judgments. Thus, the ideological nature of moral emotions translates to their discursivity that lies in modulating or determining propositional ideologemes and their processing both for their maintenance and further transit.

Lingual representation of ideologemes enables verification of the transitory processes through the expansion or reduction of their semantic structure and the frequency of their lexicalized representation 
in the respective periods. A distinction among full, partial, and acquired linguoideologemes facilitates the study of the discursive practices for constructing verbal models in substantiating power distribution of a society. Thus, full linguoideologemes are recognized as means for testability of ideological doctrines, while partial serve as means for substantiating unfalsifiability of one's beliefs, and the function of acquired linguoideologemes lies in potential contextual ideological load of nonideological knowledge.

The distribution of full linguoideologemes in the British English corpus highlights the relevance of doctrinal ideologemes in organizing the fundamental aspects of respective ideologies. A frequency analysis aided by Google Ngram Viewer has testified to the heterogeneous process of ideologemes rises and declines. The trends displayed in the frequency graphs point to the foregrounding of relevant issues in the rising ideologies of economy, finance, morality, and policy, whereas the diminution of ideologeme relevance is observed in the waning ideology of religion, as well as in those betraying the prospective decline - family and home, law and jurisprudence.

The study has proved earlier assumptions on the correlation of emotional ideologemes to the pertinent shifts in the prominent ideologies of the times. Subsequently, the gradual deterioration of interest to guilt is concurrent to the dissolving of religious egalitarianism as observed in the general decrease of term frequency mentioning the issues of religious sensations, acts and doctrines. Meanwhile, shame forefronting translated to the prominence given to manner ideologemes within the morality system. A general decline of interest to sympathy echoes the narrowing and further restriction of the issues pertaining to the fair sex, such as marital status and family matters along with the feelings of piety and gratitude. The concomitant decrease of frequency of linguoideologemes justice, crime, and punishment evinces loss of interest in the authorized retribution incurred by growing bitterness and search for consolation in the eternal justice. Though, the recognition of anger as a business related experience retains a stable interest to the emotion throughout the period, unlike resentment, the moral judgment of which condemns it to a sinful repining and exempts it from cohesive potency.

Further analysis of specific changes in the ideologeme systems of the 19th century is required to observe the trends of ideologeme transitory processes marked by discerned heterogeneity. The prospective study would also involve an in-depth analysis of ideologeme processing for building a preliminary model of ideology circulations in the Victorian times.

\section{REFERENCES}

Ablow, R. (2017). Victorian Pain. Princeton: Princeton University Press.

Ben-Ze'ev, A. (2002). Are envy, anger, and resentment moral emotions? Philosophical Explorations, 5 (2), 148-154. DOI:10.1080/10002002058538728

Bianca, M. L. (2017). The Nomiotic-Wave Theory of Mind and Inherent Logic. Newcastle upon Tyne: Cambridge Scholars Publishing.

Boddice, R. (2018). The history of emotions. Manchester: Manchester University Press.

Conley, C. A. (1986). Rape and justice in Victorian England. Victorian Studies, 29 (4), 519-536.

Dein, S. (2013). The origins of Jewish guilt: Psychological, theological, and cultural perspectives. Journal of Spirituality in Mental Health, 15 (2), 123-137. DOI: 10.1080/19349637.2012.737682

Eccleshall, R. (2002). English Conservatism since the Restoration: An introduction and anthology. London: Routledge.

Fassin, D. (2013). On resentment and ressentiment: The politics and ethics of moral emotions. Current Anthropology, 54 (3), 249-267. DOI: 10.1086/670390.

Fine, G. A. \& Sandstrom, K. (1993). Ideology in action: A pragmatic approach to a contested concept. Sociological theory, 11 (1), 21-38. DOI: 10.2307/201978

Friesen, J. P., Campbell, T. H., \& Kay, A. C. (2015). The psychological advantage of unfalsifiability: The appeal of untestable religious and political ideologies. Journal of Personality and Social Psychology, 108 (3), 515-529. DOI: 10.1037/pspp0000018 
Foucault, M. (1969). What is an author? In Modern criticism and theory: A reader. Lodge, D. (Ed.). (p. 196-210). London: Longman,

Geuss, R. (1981). The idea of a critical theory: Habermas and the Frankfurt School. Cambridge: Cambridge University Press.

Habermas, J. (1991). The structural transformation of the public sphere: An inquiry into a category of bourgeois society. Translated by Thomas Burger. Cambridge: The MIT Press.

Haidt, J. (2003). The moral emotions. In Handbook of affective sciences. Davidson R. J., Scherer K. R., Goldsmith H. H. (Eds.). (p. 852-870). Oxford: Oxford University Press.

Haidt, J. (2012). Righteous mind: Why good people are divided by politics and religion. New York: Pantheon Books.

Hardy, S.A., Nadal, A.R.C. \& Schwartz, S.J. (2017). The Integration of Personal Identity, Religious Identity, and Moral Identity in Emerging Adulthood. Identity: An International Journal of Theory and Research, 17 (2), 96-107. DOI: 10.1080/15283488.2017.1305905

Head, B.W. (1985). Ideology and social science: Destutt de Tracy and French liberalism. Dordrecht, Boston, Lancaster: Martinus Nijhoff Publishers.

Himmelfarb, G. (1995). Victorian minds: A study of intellectuals in crisis and ideologies in transition. Chicago: Elephant Paperbacks.

Hochschild, A. R. (1979). Emotion work, feeling rules, and social structure. American Journal of Sociology, 85 (3), 551-575.

Hume, D. (1978). A treatise of human nature. L. A. Selby-Bigge \& P. H. Nidditch (Eds). Oxford: Claredon Press.

Kennedy, E. (1979). "Ideology" from Destutt De Tracy to Marx. Journal of the history of ideas, 40 (3), 353-368. DOI: $10.2307 / 2709242$

Koch, G. (2015). Feeling rules - unfound treasures for the study of work cultures. In Pathways to empathy: New studies on commodification, emotional labor, and time binds. Koch, G. \& Stefanie E. B. (Eds.). (p. 123-140). Frankfurt, New York: Campus Verlag.

Lowe, B. (2007). Victorian fiction and the insights of sympathy: An alternative to the hermeneutics of suspicion. London, New York, Delhi: Anthem Press.

McAvoy, J. (2015). From ideology to feeling: Discourse, emotion, and an analytic synthesis. Qualitative Research in Psychology, 12 (1), 22-33. DOI:10.1080/14780887.2014.958357

Parsons, T. (1991). The social system. London: Routledge.

Pinich, I. (2018a). Negative self-conscious moral emotions in constructing Victorian moral identity (a corpus-based study). In Pivdennyj arkhiv. Philology: Collected paper. Kherson: Kherson State University, 76 / Pinich I. Negative self-conscious moral emotions in constructing Victorian moral identity (a corpus-based study). In Pivdennyj arkhiv. Filologichni nauky: Zbirnyk naukovyh prac'. Kherson: KhDU, 76 / Pinich I. Negative self-conscious moral emotions in constructing Victorian moral identity (a corpus-based study). In Південний архів. Філологічні науки: Збірник наукових праиь. Херсон: ХДУ, 76, 78-85.

Pinich, I. (2018b). Positive moral emotions in cultivating ideology of VICTORIAN MORALITY (a corpus-based study). In Scientific Notes. Series: Philological Sciences. Ostroh: National University of Ostroh Academy publishing house, 1 (69), 2 / Pinich I. Positive moral emotions in cultivating ideology of VICTORIAN MORALITY (a corpus-based study). In Naukovi zapysky Nacional'nogo universytetu "Ostroz'ka akademiya", seriya "Filolohiya". Ostroh: Vydavnyctvo Nacional'nogo universytetu "Ostroz'ka akademiya", 1 (69), Ch. 2 / Pinich I. Positive moral emotions in cultivating ideology of VICTORIAN MORALITY (a corpus-based study). In Наукові записки Наиіонального університету “Острозька академія", серія “Філологія”. Острог: Вид-во HaУOA, 1 (69). Ч. 2, 96-101. DOI: 10.25264/2519-2558-2018-1(69)/2-96-101 
Pinich, I. (2018c). Religious ideologemes in transition: A residue of theological virtues in the emotionalist ethics of Victorian novels. In Lege artis. Language yesterday, today, tomorrow. The journal of University of SS Cyril and Methodius in Trnava. III (1), 274-313. Warsaw: De Gruyter Open, DOI: 10.2478/lart-2018-0006.ISSN 2453-8035.

Pinich, I. (2018d). The rise of moral ideologemes in emotionalist ethics of Victorian novels (a corpusbased study). In Topical issues of Romance and Germanic philology and Applied Linguistics. Chernivtsi: Publishing House "Rodovid", 1 (15) / Pinich I. The rise of moral ideologemes in emotionalist ethics of Victorian novels (a corpus-based study). In Aktual ni problemy romanogermans koyi filologiyi ta prykladnoyi lingvistyky. Chernivci: Vydavnychyj dim "Rodovid", 1 (15) / Пініч I. The rise of moral ideologemes in emotionalist ethics of Victorian novels (a corpusbased study). In Актуальні проблеми романо-германської філологї та прикладної лінгвістики. Чернівці: Видавничий дім “Родовід”, 1 (15), 272-277.

Pinich, I. (2019). Logical and psychological aspects of ideology enactment: A descriptive approach. Forthcoming in Proceedings of international scientific and practical conference "Ad orbem per linguas", March, 20-22, Kyiv.

Purchase, S. (2007). Key Concepts in Victorian Literature. Houndmills, Basingstoke: Palgrave Macmillan.

Rosenwein, B. H. (1998). Introduction. Anger's past: The social uses of an emotion in the middle ages. Rosenwein, B. H. (Ed.). (p. 1-6). Ithaca, London: Cornell University Press.

Rosch, E. (1975). Cognitive representations of semantic categories. In Journal of Experimental Psychology: General, 104 (3), 192-233. DOI.1037/0096-3445.104.3.192

Sabbagh, C. \& Schmitt, M. (2016). Past, present, and future of social justice theory and research. In Handbook of Social Justice Theory and Research. C. Sabbagh \& M. Schmitt (Eds). (p. 1-11). New York: Springer, DOI. 10.1007/978-1-4939-3216-0_1

Sartori, G. (1969). Politics, ideology, and belief systems. The American political science review, 63 (2), $398-411$.

Slote, M. (2014). A sentimentalist theory of the mind. Oxford: Oxford University Press.

Smith, A. (2002). The theory of moral sentiments. K. Haakonssen (Ed.). Cambridge: Cambridge University Press.

Stearns, P. N. (1994). Victorian Style. In American cool: Constructing a twentieth-century emotional style. (p. 16-57). New York: NYU Press.

Thagard, P. (2008). Hot thought: Mechanisms and applications of emotional cognition. Cambridge: The MIT Press.

Thesaurus of English words and phrases classified and arranged so as to facilitate the expression of ideas and assist in literary composition. (1879). Roget, P. M. (Ed.). New York: Thomas Y. Crowell \& Co.

Van Dijk, T. A. (1998). Ideology: A multidisciplinary approach. London: Sage Publications.

Xiao, B. (2015). Morality in Victorian period. In Theory and Practice in Language Studies, 5 (9), 1815-1821. DOI: $10.17507 /$ tpls.0509.07

hihek, S. (1994). The spectre of ideology. In Mapping ideology. hihek, S. (Ed.). London, New York: Verso.

Webster's Complete Dictionary of the English Language (1886). Goodrich Ch.A., Porter N. \& Mahn C.A.F. (Eds.). London: George Bell \& Sons.

Дата надходження до редакиії 29.03.2019 р.

Ухвалено до друку 19.04.2019 р. 